\title{
Perspectives on Postharvest Biopesticides and Storage Technologies for Organic Produce
}

\author{
Robert K. Prange, ${ }^{1}$ Ali A. Ramin, ${ }^{2}$ Barbara J. Daniels-Lake, John M. DeLong, and P. Gordon Braun \\ Agriculture and Agri-Food Canada, Atlantic Food and Horticulture Research Centre, 32 Main Street, Kentville, Nova \\ Scotia, B4N 1 J5 Canada
}

\begin{abstract}
Additional index words. controlled atmosphere, hot water treatment, sprout control, decay control, fungi, bacteria, biofumigation

Abstract. Fewer postharvest technologies are available for use on organic than conventional fruits and vegetables. Even though biopesticides are perceived as likely candidates for postharvest use on organic produce, only some biopesticides will be approved as organic compounds for various reasons. An example is the definition of a biopesticide used by regulatory agencies such as the EPA which includes compounds that will not be considered organically acceptable. Fortunately, there are other existing or new technologies that could be acceptable on organic fruits and vegetables. Some examples are hot water immersion treatment or a hot water rinsing and brushing, new innovative controlled atmosphere techniques, alternative sprout control agents, naturally occurring volatiles and biofumigants. More research is needed on each of these technologies, both singly and in combination with each other.
\end{abstract}

Storage operators handling organic fruits and vegetables cannot use un-approved chemicals or treatments that are widely used on conventionally grown produce. The purpose of this paper is intended to provide an overview of biopesticides and postharvest techniques that are currently available or may become available for organic fruits and vegetables, rather than an extensive summary of all the biopesticides and technologies available for use on organic fruits and vegetables.

\section{DEFINITIONS AND REGULATORY ASPECTS}

Biopesticides are a type of pesticide. It is important to note that pests are not only separate biological organisms such as insects and fungi which negatively affect the product. The term pest includes an animal, a plant or other organism that is injurious, noxious or troublesome, whether directly or indirectly, and also any injurious, noxious or troublesome condition or organic function of the animal, plant or other organism itself (Department of Justice Canada, 2003). A pesticide is any substance intended to prevent, destroy, repel, or mitigate any of these pests. The term pesticide includes insecticides, herbicides, fungicides, and various other substances used to control pests, and (under U.S. and Canadian law) plant regulators, defoliants, and desiccants (U.S. Environmental Protection Agency, 2005a). Biopesticides are possible candidates for postharvest use on organic produce because they are derived from natural materials such as animals, plants, bacteria, and certain minerals (U.S. Environmental Protection Agency, 2005b). Using the U.S. Environmental Protection Agency (EPA)

Contribution \# 2314, Atlantic Food and Horticulture Research Centre, Agriculture and Agri-Food Canada. The authors thank W. Schotsmans and D. Nichols for reviewing this manuscript. This work was supported in part by a fellowship to A.A. Ramin from Isfahan University of Technology, Isfahan, Iran.

${ }^{1}$ Corresponding author, e-mail PrangeR@agr.gc.ca. ${ }^{2}$ Department of Horticulture, College of Agriculture, Isfahan University of Technology, Isfahan, Iran. definition of biopesticide, there are three major biopesticide classes:

1) Microbial pesticides, which consist of a micro-organism (e.g., a bacterium, fungus, virus or protozoan) as the active ingredient.

2) Plant-incorporated protectants (PIPs), which are pesticidal substances that plants produce from genetic material that has been added to the plant, e.g., insertion of the gene for the Bt insecticidal protein into the plant's genetic material.

3) Biochemical pesticides, which are naturally occurring substances that control pests by nontoxic mechanisms, e.g., insect sex pheromones, scented plant extracts that attract insect pests to traps and plant growth regulators. It is sometimes difficult to determine whether a substance is a biochemical biopesticide and there is an EPA special committee to make such decisions.

Use of biopesticides in the U.S. is regulated by the EPA. A large number of EPA-approved biopesticides are listed on its website (U.S. Environmental Protection Agency, 2005c), although only a small number of these may have potential postharvest application (Table 1). There is limited access to these biopesticides outside the U.S. and only a small number of EPA-approved products are also approved in other countries such as Canada (Health Canada Pest Management Regulatory Agency, 2005) (Table 1). Depending on regulations in each country, use of a nonregistered biopesticide on imported fruits and vegetables could be used as a nontariff trade barrier.

With regard to the use of biopesticides on

Table 1. EPA-approved biopesticides which may have potential postharvest applications, arranged by category.

General postharvest biopesticides

Harpin protein and $\alpha \beta$ harpin protein Kaolin $^{2}$

Anti-microbial postharvest biopesticides

Fatty acid monoesters + glycerol/propanediol

Hydrogen peroxide ${ }^{z}$

Yeast (Saccharomyces cerevisiae) extract hydrolysate

Anti-fungal postharvest biopesticides

Bacillus subtilis strain QST 713

Coniothyrium minitans CON/M/91-08

Diallyl sulfides (DADs)

Gamma aminobutyric acid (GABA) and L-glutamic acid

$\mathrm{K}$ bicarbonate and $\mathrm{Na}$ bicarbonate

K dihydrogen phosphate

Pseudomonas syringae (various strains)

Rhamnolipid biosurfactant

Trichoderma harzianum (various strains)

Growth regulator postharvest biopesticides

1, 4-Dimethylnaphthalene (potato sprout control)

2, 6-Diisopropylnaphthalene (potato sprout control )

Aminovinylglycine (AVG) (anti-ethylene) ${ }^{z}$

1-Methylcyclopropene (1-MCP) (anti-ethylene) ${ }^{z}$

Silver nitrate (anti-ethylene)

Ethylene $^{y}$

Indole-3-butyric acid

Cytokinin, kinetin, N6-benzyladenine ${ }^{z}$

Gibberellins ${ }^{2}$

Lysophosphatidylethanolamine (LPE)

${ }^{\mathrm{z}}$ Also approved for use in Canada.

${ }^{y}$ Approved in Canada, but not in the U.S., as a potato sprout control agent. 
Table 2. USDA National Organic Program (NOP)approved substances oriented to postharvest use. $^{z}$ This simplified list does not include any specific applications or restrictions for use listed on the website.

Ascorbic acid

Ca materials

$\mathrm{Cl}$ materials

Ethylene

Flavours

$\mathrm{H} 2 \mathrm{O} 2$

Kaolin

Lignin sulfonate

$\mathrm{Mg}$ materials

Ozone

$\mathrm{O}_{2}, \mathrm{~N}_{2}$, and $\mathrm{CO}_{2}$

Phosphoric acid

$\mathrm{K}$ materials

$\mathrm{SiO}_{2}$

$\mathrm{Na}$ materials

$\mathrm{SO}_{2}$

Waxes

Tocopherols

${ }^{2}$ Taken from www.ams.usda.gov/nop/NOP/standards/.

organic fruits and vegetables, one must refer to additional documentation of chemicals approved for use on organic horticultural crops. In the U.S., the U.S.D.A. National Organic Program (NOP) regulates generic substances for use in organic agriculture and provides a list of these on its website (www.ams.usda. gov/nop/NOP/standards/). Substances from this list that may have a postharvest application are given in Table 2. Also, in the U.S., the nonprofit organisation Organic Materials Review Institute (OMRI) provides a service to the industry by reviewing products for manufacturers of substances to be used in or on organic crops, livestock and handling and processing. Manufacturers benefit from having their products reviewed by OMRI because they can maintain their formulation or process as confidential. OMRI publishes 1) a Generic Materials List, which conforms to the US NOP National List, plus 2) a Brand Name Products List, which lists commercial products assessed by OMRI as meeting NOPRule(Organic Materials Review Institute, 2005). Even if the active ingredient in a product is on the list of approved ingredients of the NOP, the inert ingredients or the manufacturing process still need to be approved. Manufacturers must submit products for review and approval to be included on the OMRI Brand Name Products List.

It is not easy to be certain which postharvest biopesticide products and processes are acceptable for organic production. There are no internationally recognized regulatory agencies harmonising the approval of either biopesticides or products acceptable for use on organic fruits and vegetables. Regulations vary among nations, and in many countries approved biopesticide and organic products lists do not exist. Even within the U.S., which has a sophisticated framework for approval of both biopesticides and organic substances, harmonisation does not occur. The U.S. EPA, a federal agency, regulates biopesticides whereas organic substances approval is conducted by the USDA NOP (another federal agency).

One cannot assume that a biopesticide approved by the EPA will automatically be allowed for use on organic fruits and vegetables. For example, the PIPs, which are biopesticides according to the EPA, will not be acceptable for use on organic fruits and vegetables because they are the products of genetic engineering and this is prohibited in organic production. Furthermore, it is not certain that all items on the EPA Biopesticide list (Table 1) meet the EPA biopesticide requirement of being derived from naturally occurring materials. An example is 1-methylcyclopropene (1-MCP), which is listed as a biopesticide (Table 1) but it is not known to occur naturally (Tamm et al., 2005) and, as a synthetic substance, it is unlikely that it will be put on the NOP list of organic materials. Finally, U.S. regulatory approval as a biopesticide or as an organic substance does not include any guarantee of postharvest efficacy or economic benefit, nor does it supersede existing food, pesticide and health laws and regulations.

\section{SOME POSTHARVEST METHODS WITH POTENTIAL FOR ORGANIC APPLICATION}

A promising nonchemical postharvest method for use on organic fruits and vegetables is prestorage hot water treatment, either as a hot water immersion treatment (HWT) or hot water rinsing and brushing (HWRB) (Fallik, 2004; McDonald et al., 2005). Since these are nonchemical technologies, there are no government approvals required before being used by organic growers. Although these two technologies have been employed on a wide variety of horticultural crops (Fallik, 2004), only a few trials have been conducted on organic fruits and none on organic vegetables. Maxin et al. (2005) and Trierweiler et al. (2003) have shown that HWT controls several postharvest decay problems in organic apples without loss of quality and Porat et al. (2000) have shown that HWRB reduces postharvest decay in organic citrus fruit.

The use of controlled atmospheres $(\mathrm{CA})$ is a known and effective technology for use on many fruits and vegetables and it is an acceptable organic postharvest technology when the CA uses only $\mathrm{O}_{2}, \mathrm{CO}_{2}$, and $\mathrm{N}_{2}$ (Table 2). There are a number of new innovations in CA that can provide considerable benefit to organic fruits and vegetables including humidity monitoring and control, super-atmospheric oxygen, hypobaric and hyperbaric storage (Prange et al., 2005 and references cited therein; Romanazzi et al., 2001). One of these new innovations is the introduction of a commercial technology (HarvestWatch) which uses a nondestructive chlorophyll fluorescence measurement to dynamically control oxygen during $\mathrm{CA}$ storage to prevent reduction of $\mathrm{O}_{2}$ concentration to damaging levels (Prange et al., 2003; DeLong et al., 2004; Zanella et al., 2005). This is very useful in organic apple storage to maximise quality retention. Maintaining the storage $\mathrm{O}_{2}$ below $1.0 \mathrm{kPa}$ eliminates the need for a prestorage dip containing an antioxidant (diphenylamine) and fungicide to control the appearance during storage of superficial scald and rots, respectively (DeLong et al., 2004; Zanella et al., 2005).

Worldwide, the most commonly used sprout control agent on potatoes is 1-isopropyl-N-3-chlorophenyl carbamate (CIPC ). It is among the three pesticides most frequently found in the diet of the average American and comprises $90 \%$ of the total synthetic chemical residue in United States potatoes (Gartrell et al., 1986; Gunderson, 1988; Vaughn and Spencer, 1991). A number of alternative potato sprout inhibitors have been found such as ethylene, 1, 4-dimethylnaphthalene (1,4 DMN), 2,6diisopropylnaphthalene (2,6 DIPN), carvone, clove oil and peroxides (Prange et al., 1997; Kleinkopf et al., 2003). Several have been registered and are being tested or used in commercial practice. Both 1,4 DMN and 2,6 DIPN are approved biopesticides for potato sprout control by the EPA (Table 1). Synthetic $1,4 \mathrm{DMN}$ is not approved as an organic treatment (U.S. Dept. of Agriculture, 2002) and the same nonapproval is likely for 2,6 DIPN since it is synthetically produced and is not known to occur naturally in plants. Clove oil is a biopesticide, approved by the EPA to attract and/or kill insects rather than for use as a sprout control agent (U.S. Environmental Protection Agency, 2005c). A commercial aerosol version of clove oil (Biox-ATM or eugenol) is approved by OMRI for use as an organic sprout inhibitor in some western U.S. states (Kleinkopf et al., 2003). Along with clove oil, ethylene is a viable organic sprout control agent. It effectively controls sprouting (Prange et al., 1998), is already an NOP-accepted organic material for postharvest ripening of tropical fruit and citrus degreening (Table 2) and has government approval as a sprout control agent in Canada (Table 1) and the U.K. In the U.K. it is already in use on residue-free potatoes (Anonymous, 2005).

\section{NATURAL VOLATILES AND BIOFUMIGATION}

Recently there has been an increased appreciation of the potential anti-pest role of plantproduced volatiles and other volatile organic compounds, e.g., ethanol and acetaldehyde (Pesis, 2005), acetic acid (Sholberg et al., 2000, 2004) as well as biologically produced volatiles (Mercier and Marrone, 2006). Utama et al. (2002) surveyed a number of volatile organic compounds (acetaldehyde, benzaldehyde, cinnamaldehyde, ethanol, benzyl alcohol, nerolidol, 2-nonanone, $\beta$-ionone and ethyl formate) on the growth of several fungi and bacteria. They concluded that the aldehydes are the strongest growth inhibitors and the most lethal to fungal spores and mycelia and bacterial cells. Recently the fungus Muscodor albus (Worapong et al., 2001) was discovered to act as a biofumigant, producing a complex of relatively innocuous low molecular weight volatiles that inhibits or kills a wide range of microorganisms (Ezra et al., 2004; Strobel et al., 2001). Many of these compounds are wellknown as natural constituents of fresh leaves, fruit, wine, rum and blue cheese aromas, other natural essential oils, olive oil, and vegetable 
oil (Anonymous, 2004). Muscodor albus controls bacterial and fungal decay pathogens in vitro and in various tested fruits, e.g., apple, peach, grape, and has been used for whole room fumigation of lemons (Ezra and Strobel, 2003; Mercier and Jiménez, 2004; Mercier and Smilanick, 2005; Mercier et al., 2005; Ramin et al., 2005; Strobel et al., 2001).

\section{CONCLUDING REMARKS}

Postharvest research is needed to investigate the many existing and new postharvest organic products/methods for consideration and approval by the appropriate agencies, e.g., the USDA NOP and OMRI in the U.S. Since many of these products/technologies have limited residual control or benefit compared with products available to nonorganic growers, there is a need to conduct more research on combining products/technologies in order to provide sufficient benefits. However, the research and pursuit of organic approvals is largely dependent on corporate initiative. There is still limited commercial corporate activity in postharvest products/technologies for the organic horticultural industry, but this is likely to improve if interest from researchers and businesses is increased.

\section{Literature Cited}

Anonymous. 2004. Muscodor albus strain QST 20799; notice of filing a pesticide petition to establish an exemption from tolerance for a certain pesticide in or on food. U.S. EPA Fed. Reg. 69(67):1-16.http://www.epa.gov/fedrgstr/EPAPEST/2004/April/Day-07/p7476.htm.

Anonymous. 2005. MBM invests in residue-free potatoes. http://www.foodeast.com/news/newsarchive/news 1955.asp.http://www.foodeast. com/processors/FoodEastFlyer28.pdf.

DeLong, J.M., R.K. Prange, J.C. Leyte, and P.A. Harrison. 2004. A new technology that determines low- $\mathrm{O}_{2}$ thresholds in controlled-atmospherestored apples. HortTechnology 14:262-266.

Department of Justice Canada. 2003. Pest Control Products Act of Canada 2002.2 Nov. 2005. http:// laws.justice.gc.ca/en/P-9.01/92455.html.

Ezra, D., W.M. Hess, and G.A. Strobel. 2004. New endophytic isolates of Muscodor albus, a volatile-antibiotic-producing fungus. Microbiology 150:4023-4031.

Ezra, D. and G.A. Strobel. 2003. Effect of substrate on the bioactivity of volatile antimicrobials produced by Muscodor albus. Plant Sci. 165:1229-1238.

Fallik, E. 2004. Prestorage hot water treatments (immersion, rinsing and brushing). Postharvest Biol. Technol. 32:125-134.

Gartrell, M.J., J.C. Craun, D.S. Podrebarac, and E.L. Gunderson. 1986. Pesticides, selected elements, and other chemicals in adult total diet samples, October 1980-March 1982. J.Assn. Offic. Anal.
Chem. 69:146-159.

Gunderson, E.L. 1988. FDA total diet study, April 1982-April 1984, dietary intakes of pesticides, selected elements and other chemicals. J. Assn. Offic. Anal. Chem. 71:1200-1209.

Health Canada Pest Management Regulatory Agency. 2005. Update on reduced-risk pesticides in Canada. 2 Nov. 2005.(http://www.pmra-arla. gc.ca/english/pdf/rr/rr2005-01-e.pdf.

Kleinkopf, G.E., N.A. Oberg, and N.L. Olsen. 2003. Sprout inhibition in storage: Current status, new chemistries, and natural compounds. Amer. J. Potato Res. 80:317-327.

Maxin, P., S. Huyskens-Keil, K. Klopp, and G. Ebert. 2005. Control of postharvest decay in organic grown apples by hot water treatment. Acta Hort. 682:2153-2157.

Mercier, J. and J.I. Jiménez. 2004 . Control of fungal decay of apples and peaches by the biofumigation fungus Muscodor albus. Postharvest Biol. Technol. 31:1-8.

Mercier, J. and P.G. Marrone. 2006. Biological control of microbial spoilage of fresh produce, p. 523-539. In: G.M. Sapers, J.R. Gorny, and A.E. Yousef (eds.). Microbiology of fruits and vegetables. CRC Press, Taylor \& Francis Group, Boca Raton, Fla.

Mercier, J. and J.L. Smilanick. 2005. Control of green mold and sour rot of stored lemon by biofumigation with Muscodor albus. Biol. Control 32:401-407.

Mercier, J., P. Walgenbach, and J.I. Jiménez. 2005. Biofumigation with Muscodor albus pads for controlling decay in commercial table grape cartons. HortScience 40:1144 (abstr.).

McDonald, K.L., M.R. McConchie, A. Bokshi, and S.C. Morris. 2005. Heat treatment:Anatural way to inhibit postharvest diseases in rockmelon. Acta Hort. 682:2029-2033.

Organic Materials Review Institute. 2005. OMRI generic materials list (GML) and brand name products list (BNPL). 2 Nov. 2005. http://www. omri.org/index.html.

Pesis, E. 2005. The role of the anaerobic metabolites, acetaldehyde and ethanol, in fruit ripening, enhancement of fruit quality and fruit deterioration. Postharvest Biol. Technol. 27:1-19.

Porat, R., A. Daus, B. Weiss, L. Cohen, E. Fallik, and S. Droby. 2000. Reduction of postharvest decay in organic citrus fruit by a short hot water brushing treatment. Postharvest Biol. Technol. 18:151-157.

Prange, R.K., J.M. DeLong, P.A. Harrison, J.C. Leyte, and S.D. McLean. 2003. Oxygen concentration affects chlorophyll fluorescence in chlorophyllcontaining fruit and vegetables. J. Amer. Soc. Hort. Sci. 128:603-607.

Prange, R.K., J.M. DeLong, B.J. Daniels-Lake, and P.A. Harrison. 2005. Innovation in controlled atmosphere technology. Stewart Postharvest Rev. 1:3. Paper 9. 7 Dec. 2005. http://www.stewartpostharvest.com/October 2005/Prange.pdf.

Prange, R.K., W. Kalt, B. Daniels-Lake, C.L. Liew, J. Walsh, P. Dean, R. Coffin, and R. Page. 1997. Alternatives to currently used potato sprout suppressants. Postharvest News Info. 8:37N-40N. Prange, R.K., W. Kalt, B.J. Daniels-Lake, C.L. Liew,
R.T. Page, J.R. Walsh, P. Dean, and R. Coffin. 1998. Using ethylene as a sprout control agent in stored 'Russet Burbank' potatoes. J. Amer. Soc. Hort. Sci. 123:463-469.

Ramin, A. A., P.G. Braun, R.K. Prange, and J.M. DeLong. 2005. In vitro effects of Muscodor albus and three volatile components on growth of selected postharvest microorganisms. HortScience 40:2109-2114.

Romanazzi, G., F. Nigro, A. Ippolito, and M. Salerno. 2001. Effect of short hypobaric treatments on postharvest rots of sweet cherries, strawberries and table grapes. Postharvest Biol. Technol. 22:1-6.

Sholberg, P., P. Haag, R. Hocking, and K. Bedford. 2000. The use of vinegar vapor to reduce postharvest decay of harvested fruit. HortScience 35:898-903.

Sholberg, P.L., T. Shephard, P. Randall, and L. Moyls. 2004. Use of measured concentrations of acetic acid vapour to control postharvest decay in d'Anjou pears. Postharvest Biol. Technol. 32:89-98.

Strobel, G.A., E. Drike, J. Sears, and C. Markworth. 2001. Volatile antimicrobials from Muscodor albus, a novel endophytic fungus. Microbiology 147:2943-2950.

Tamm, L., B. Speiser, and F. Weibel. 2005. Evaluation of 1-MCP for use in organic farming (summary). Res. Inst. Org. Agr. (FiBL), Frick, Switzerland.

Treierweiler B., H. Schirmer, and B. Tauscher. 2003. Hot water treatment to control Gloeosporium disease on apples during long-term storage. J. App. Bot.-Angewandte Botanik 77:156-159.

U.S. Dept. of Agriculture. 2002. Agriculture Marketing Services, National Organic Program, National List Information, Petitioned Substances Database. 2 Nov. 2005. http://www.ams.usda. gov/nop/NationalList/PetitionedSubstancesDatabase.htm.

U.S. Environmental Protection Agency.2005a. About pesticides. 2 Nov. 2005. http://www.epa. gov/pesticides/about/\#what_pest.

U.S. Environmental Protection Agency. 2005b. Types of Pesticides. 2 Nov. 2005. http://www.epa. gov/pesticides/about/types.htm\#biopesticides.

U.S. Environmental Protection Agency. 2005c. Biopesticide Active Ingredient Fact Sheets. 2 Nov. 2005. http://www.epa.gov/pesticides/ biopesticides/ingredients/index.htm.

Utama, I.M., R.B. Wills, S. Ben-Yehoshua, and C. Kuek. 2002. In vitro efficacy of plant volatiles for inhibiting the growth of fruit and vegetable decay organisms. J. Agr. Food Chem. 50:6371-6377.

Vaughn, S.F. and G.F. Spencer. 1991. Volatile monoterpenes inhibit potato tuber sprouting. Amer. Potato J. 68:821-831.

Worapong, J., G. A. Strobel, E.J. Ford, J.Y. Li, G. Baird, and W.M. Hess. 2001. Muscodor albus anam. gen. et sp. nov., an endophyte from Cinnamomum zeylanicum. Mycotaxon 79:67-79.

Zanella A, P. Cazzanelli, A. Panarese, A. Coser, M. Cecchinel, and O. Rossi. 2005. Fruitfluorescence response to low oxygen stress: Modern storage technologies compared to 1-MCP treatment of apple. Acta Hort. 682:1535-1542. 